УДК 657.1

Skrypnyk M. I.

Associate Professor, Doctor of Economics, Head of Accounting and Auditing, Kyiv National University of Technology and Design, Kyiv, Ukraine, e-mail: margarita1111@ukr.net; ORCID ID: 0000-0002-6205-0754

Vyhivska I. $M$.

Associate Professor, PhD in Economics, Assistant Professor of Accounting and Auditing department, Zhytomyr State Technological University, Zhytomir, Ukraine, e-mail: virina1407@gmail.com; ORCID ID: 0000-0002-4974-5834

Grabchuk I. L.

Associate Professor, PhD in Economics, Assistant Professor of Accounting and Auditing department, Zhytomyr State Technological University, Zhytomyr, Ukraine, e-mail: grabchuk0208@gmail.com; ORCID ID: 0000-0003-3664-7765

Hryhorevska 0.0 . Associate Professor, PhD in Economics, Assistant Professor of Accounting and Auditing department, Kyiv National University of Technology and Design, Kyiv, Ukraine, e-mail: lenazelenina@ukr.net; ORCID ID: 0000-0001-8279-3523

\title{
IDENTIFICATION OF PHARMACEUTICAL PRODUCTS IN ACCOUNTING SYSTEM: PROBLEMS OF HARMONIZATION
}

In the article it is set a problem of substantiation of the essence and components of pharmaceutical products as an object of accounting on the basis of comparison of existing international and national classification standards, which will facilitate the improvement of accounting of pharmaceutical products. In the research process there were used methods of observation, comparison, analysis, synthesis, generalization and econometric-statistical method. In the article it is defined the list of components of pharmaceutical products based on the analysis of regulations of existing normative documents (the Law of Ukraine "On Medicines", the Ukrainian Classification of Goods for Foreign Economic Activity (UCGFEA), which is the commodity nomenclature of Customs Tariff of Ukraine (CTU is based on the Harmonized System of Description and Coding of Goods of the World Customs Organization and the Combined Nomenclature of EU), "Classifications of Types of Economic Activities" (SC 009: 2010, CTEA2010)). It was established that under pharmaceutical goods as an object of accounting should be understood the goods, finished products, raw materials and materials, semi-finished products and component parts, semi-finished products of own production and customary raw materials intended for sale (production, processing) by the entities of pharmaceutical market in accordance with the requirements and standards of state and international levels in the field of pharmacy. The components of pharmaceutical products are harmonized in accordance with the domestic classifiers of activities and individual entity of accounting: (goods, finished products, raw materials and materials, semi-finished products and component parts, semi-finished products of own production and customary raw materials intended for sale (production, processing) by entities of pharmaceutical market in accordance with the requirements of state and international standards in the field of pharmacy). It is substantiated that they are attributed to certain groups of accounting accounts. The proposals provide the improved pharmacy management accounting and minimize its manufacturing and commercial risks.

Keywords: pharmaceutical goods, pharmaceutical product, pharmaceutical activity, medicinal product, accounting system.

JEL Classification: I10, M41.

Formula: 0; Fig: 0; Tables: 2; Ref.: 12.

Скрипник М. I.

доцент, доктор економічних наук, завідувач кафедри обліку і аудиту, Київський національний університет технологій та дизайну, м. Київ, Україна, e-mail: margarita1111@ukr.net; ORCID ID: 0000-0002-6205-0754

Вигівська I. M.

дочент, кандидат економічних наук, дочент кафедри обліку і аудиту, Житомирський державний технологічний університет, м. Житомир, Україна, e-mail:virina1407@gmail.com; ORCID ID: 0000-0002-4974-5834

Грабчук I. Л.

дочент, кандидат економічних наук, дочент кафедри обліку і аудиту, Житомирський державний технологічний університет, м. Житомир, Україна, e-mail: grabchuk0208@gmail.com; ORCID ID: 0000-0003-3664-7765 
Григоревська О. О.

доцент, кандидат економічних наук, доцент кафедри обліку і аудиту, Київський національний університет технологій та дизайну, м. Київ, Украйна, e-mail: lenazelenina@ukr.net; ORCID ID: 0000-0001-8279-3523

\section{ІДЕНТИФІКАЦІЯ ФАРМАЦЕВТИЧНИХ ТОВАРІВ В СИСТЕМІ РАХУНКІВ БУХГАЛТЕРСЬКОГО ОБЛІКУ: ПРОБЛЕМИ ГАРМОНІЗАЩЇ}

У статті поставлено задачу обгрунтування сутності та складових фармацевтичних товарів як об'єкту бухгалтерського обліку на основі порівняння діючих міжнародних та національних класифікаційних стандартів, що сприятиме удосконаленню бухгалтерського обліку фармацевтичних товарів. У процесі дослідження використано методи спостереження, порівняння, аналізу, синтезу, узагальнення та економіко-статистичний метод. В статті на основі аналізу положень діючих нормативних документів (Закону України «Про лікарські засоби», Української класифікації товарів зовнішньоекономічної діяльності (УКТЗЕД), яка $\epsilon$ товарною номенклатурою Митного тарифу України (МТУ базується на Гармонізованій системі опису та кодування товарів Всесвітньої митної організації і Комбінованій номенклатурі $(\mathrm{C})$ ), «Класифікації видів економічної діяльності» (ДК 009:2010, КВЕД-2010)) визначено перелік складових фармацевтичних товарів. Встановлено, що під фармацевтичними товарами як об'єктом бухгалтерського обліку слід розуміти товари, готову продукцію, сировину й матеріали, купівельні напівфабрикати i комплектуючі вироби, напівфабрикати власного виробництва та давальницьку сировину, які призначені для продажу (виробництва, переробки) суб'єктами фармацевтичного ринку відповідно до вимог та стандартів державного та міжнародного рівнів у сфері фармації. Гармонізовано складові фармацевтичних товарів відповідно до вітчизняних класифікаторів діяльності та окремих об'єктів бухгалтерського обліку: (товари, готова продукція, сировина й матеріали, купівельні напівфабрикати й комплектуючі вироби, напівфабрикати власного виробництва та давальницька сировина, які призначені для продажу (виробництва, переробки) суб'єктами фармацевтичного ринку відповідно до вимог державних та міжнародних стандартів у сфері фармації). Обгрунтовано їх віднесення до певних груп рахунків бухгалтерського обліку. Пропозиції забезпечують удосконалення облікового забезпечення управління фармацевтичним підприємством та мінімізують його виробничі та комерційні ризики.

Ключові слова: фармацевтичний товар, фармацевтичний продукт, фармацевтична діяльність, лікарський засіб, система рахунків бухгалтерського обліку

Формул: 0; рис.: 0, табл.: 2, бібл.: 12

Скрыпник М. И.

дочент, доктор экономических наук, заведуюший кафедрой учета и аудита, Киевский национальный университет технологий и дизайна, г.Киев, Украина, e-mail: margarita1111@ukr.net; ORCID ID: 0000-0002-6205-0754

Выговская И. Н.

дочент, кандидат экономических наук, доцент кафедры учета и аудита, Житомирский государственный технологический университет, г. Житомир, Украина, e-mail:virina1407@gmail.com; ORCID ID: 0000-0002-4974-5834

Грабчук И.Л.

доцент, кандидат экономических наук, доцент кафедры учета и аудита, Житомирский государственный технологический университет, г Житомир, Украина, e-mail: grabchuk0208@gmail.com; ORCID ID:0000-0003-3664-7765

Григоревская Е. A.

доцент, кандидт экономических наук, дочент кафедры учета и аудита, Киевский национальный университет технологий и дизайна, г. Киев, Украина, e-mail: lenazelenina@ukr.net; ORCID ID: 0000-0001-8279-3523

\section{ИДЕНТИФИКАЦИЯ ФАРМАЦЕВТИЧЕСКИХ ТОВАРОВ В СИСТЕМЕ СЧЕТОВ БУХГАЛТЕРСКОГО УЧЕТА: ПРОБЛЕМЫ ГАРМОНИЗАЦИИ}

В статье поставлена задача обоснования сущности и составляющих фармацевтических товаров как объекта бухгалтерского учета на основе сравнения действующих международных и национальных классификационных стандартов, что будет способствовать совершенствованию бухгалтерского учета фармацевтических товаров. В процессе исследования использованы методы наблюдения, сравнения, анализа, синтеза, обобщения и экономико-статистический метод. В статье на основе анализа положений действующих нормативных документов (Закона Украины «О 
лекарственных средствах», Украинской классификации товаров внешнеэкономической деятельности (УКТВЭД), которая является товарной номенклатурой Таможенного тарифа Украины (ТТУ базируется на Гармонизированной системе описания и кодирования товаров Всемирной таможенной организации и Комбинированной номенклатуре ЕC), «Классификации видов экономической деятельности» (ДК 009: 2010, КВЭД-2010)) определен перечень составляющих фармацевтических товаров. Установлено, что фармацевтическими товарами как объектом бухгалтерского учета следует понимать товары, готовая продукция, сырье и материалы, покупные полуфабрикаты и комплектующие изделия, полуфабрикаты собственного производства и давальческое сырье, которые предназначены для продажи (производства, переработки) субъектами фармацевтического рынка в соответствии с требованиями и стандартами государственного и международного уровней в сфере фармации. Гармонизированы составляющие фармацевтических товаров в соответствии с отечественными классификаторов деятельности и отдельных объектов бухгалтерского учета: (товары, готовая продукция, сырье и материалы, покупные полуфабрикаты и комплектующие изделия, полуфабрикаты собственного производства и давальческое сырье, предназначенные для продажи (производства, переработки) суб объектами фармацевтического рынка в соответствии с требованиями государственных и международных стандартов в сфере фармации). Обосновано их отнесения к определенным группам счетов бухгалтерского учета. Предложения обеспечивающих совершенствование учетной обеспечения управления фармацевтическим предприятием и минимизируют его производственные и коммерческие риски.

Ключевые слова: фармацевтический продукт, фармацевтический продукт, фармацевтическая деятельность, лекарственное средство, система счетов бухгалтерского учета

Формул: 0; рис.: 0, табл.: 2, библ.: 12

Introduction. The global pharmaceutical industry involves the production of medicinal products of all possible pharmaceutical forms - these are drugs that solve the medical problems common to hundreds of millions of people and, simultaneously, generate large volumes of sales and profits for pharmaceutical companies [1]. The trade of medicinal and pharmaceutical products and the growth of their volume production have steadily increased since 2002. The world turnover (except EU countries) has increased almost threefold from 76 billion Euros in 2002 to 220 billion Euros in 2016 (annual growth of 7, 8\%). In the same period, the trade within the Europe has increased more than twice from 156 billion to 327 billion Euros, that is equal to an average annual growth of 5, 4\% [2]. In its turn, the total volume of pharmaceutical market of medicines in Ukraine, including retail and hospital segments, increased by 16,9\% in 2016 and reached UAH 58,7 billion, in natural - 1,1 billion packets (with a growth of 4,0\%). In January-March 2017 the volume of pharmaceuticals and materials was UAH 6121, 3 million, of which for UAH 807, 1 million was sold outside Ukraine. By the end of 2017, the pharmaceutical industry experts predict its growth by $14-18 \%$ in money, and in kind - by $2,9 \%$ [3].

The medicines are manufactured in accordance with industry standards, which are developed on the basis of pharmacological protocols [4]. The role of an accountant in this case is to reflect in the accounting system data about: the quantity and composition of ingredients, packaging, which are necessary for the medicines production; technological losses that arise in the manufacture of drugs. The relevant information is used to calculate the cost of the drug and develop a retail price list. Consequently, there is a need to study such object of accounting as pharmaceutical products (essence, elements and classifications). The urgency of the issue is intensified by the introduction of medical reform, the development of pharmaceutical companies and the passing them the international quality certification.

Analysis of research and problem statement. The investigation of accounting of expenses of pharmaceutical companies, accounting organizations in the pharmaceutical sphere, forming the cost of production and quality management was made by: O.A. Demchenko, N.B. Ershova, O.P. Ruba, O.M. Saienko, L.V. Titenko, O.A. Fedorov, O.A. Yurchenko and others. Without detracting their contribution, we note that the issues of the economic nature of the pharmaceutical goods as an object of accounting, their classification and the use of accounts, which should be applied taking into account the specifics of pharmaceutical enterprises, remain open to the full extent.

The purpose of the article is to substantiate the essence and components of pharmaceutical products as an object of accounting on the basis of comparison of existing international and national classification standards, which will facilitate the improvement of accounting of pharmaceutical products.

In the process of research, methods of observation, comparison, analysis, synthesis, generalization and economic-statistical method were used.

Research results. In terms of accounting, "the goods are tangible assets acquired (received) and held by an enterprise / institution for the purpose of resale” [5]. Taking into account that the goods are a kind of store, its components may be various tangible current assets, intended for sale (often - goods and finished products) and / or 
use in production (raw materials, materials, semi-finished products), processing (customer's raw materials) [6 , p. 2829]. Products of the pharmaceutical industry include medicines, drugs and pharmaceutical drugs that are special products. In addition to the consumer properties of product, the suitability of any medicinal product is determined by the following factors: therapeutic efficacy, established by pharmacological and clinical trials; conformity of the quality of medicinal products with regulatory requirements regarding identity, purity and quantitative content; security; accessibility" [7]. Taking it in account, as well as the specificity of the subject area of research, it can be noted that pharmaceutical products have a number of features: 1) medicines are a special commodity, because they affect the most valuable thing that a person has - his health; 2) there is always demand for medicines; 3) the manufacture and sale of pharmaceutical products are strictly regulated by law; 4) increased control, accounting and prevention of illicit trafficking in narcotic drugs and psychotropic substances (increase the costs of meeting the conditions of production, storage, distribution and sale). Consequently, these properties affect the accounting of pharmaceutical products, their classification and attribution to a certain group of objects of accounting.

In pharmacy, the finished product is not stand out from the commodity, both concepts are characterized as: "appointed by the manufacturer for the release or sale, meets the standards and is provided with a quality passport". But the concept of "product" is special, because the process of its creation in this field involves the passage of specific stages of production, associated with specific conditions of work, equipment, sterility, chemical composition of substances, raw materials. Important components of a product are quality (for a medicinal product -efficiency and safety of use, compliance with specifications), competitiveness and economic benefits. Pharmaceutical product that was under a state examination in the Ministry of Health and is registered, receives the status of a medicinal product [7].

According to Art. 2 of the Law of Ukraine "On Medicinal Products" the medicinal product - is any substance or combination of substances (one or more active pharmaceutical ingredients (APIs) and auxiliary substances) possessing properties intended for the treatment or prophylaxis of diseases in people or any substance or a combination of substances (one or more APIs and auxiliary substances) that can be used to prevent pregnancy, revitalization, correct or modify physiological functions in humans by pharmacological, immunological or metabolic action or to establish medical diagnosis [8]. Thus, the conceptual apparatus in the pharmacy is diverse: product, goods, finished product, pharmaceutical product, medicinal product.

Note that pharmaceutical products do not always pass all stages of production in one enterprise. Often, pharmaceutical companies purchase finished or almost finished products that only require packaging, or processing and assembly, which brings the product to a condition for sale and, accordingly, for consumption. For accounting purposes, such objects are displayed on the account 202 "Purchase semi-finished products and component parts" or on the account 25 "Semi-finished products" (own production). In addition to these types of stocks, industrial pharmaceutical companies also purchase raw materials and materials in the form of various substances (which as an object of accounting, are reflected in the account 201 "Raw materials") for the purpose of carrying out their main activities (manufacture of medicines and other products), which are usually intended for use in production, but can also be sold as goods to other economic entities. Considering that such semi-finished products and substances (various powders, mixtures) are ready for sale even without final packaging, for example, for establishments which make mixtures itself, ointments and other preparations consisting of a mixture of certain ingredients - they can also be attributed to the research object - is pharmaceutical and accounting as well as other components of this group.

It should be noted that pharmaceutical companies, in the absence of the necessary technical support for the processing of raw materials and / or packaging of products, may receive services under a tolling contract. So, there is an off-balance-sheet accounting of tolling raw materials in the account 022 "Materials are accepted for processing“, and assets transferred to third parties in accounting are displayed in the account 206 "Materials transferred to processing". Therefore, tolling materials in the context of materials (substances) are also included in the pharmaceutical products. By trading, all the above-mentioned objects and results of activity are accounted in the account 28 "Goods".

The components allowed to identify the pharmaceutical goods as an object of accounting - goods, finished products, raw materials and materials, semi-finished products and components, semi-finished products of own production and tolling raw materials, which are intended for sale (production, processing) by the subjects of the pharmaceutical market in accordance with requirements state and international standards in the field of pharmacy.

The main classifier of enterprise activity is "Classification of types of economic activity” (DK 009: 2010, CTEA-2010). For CTEA -2010, pharmaceutical products and goods are related in two sections: C "Processing Industry" and G "Wholesale and retail trade". According to the CTEA, the following objects can be distinguished: pharmaceuticals and materials, pharmaceuticals and medical products. These three groups are distinguished according to the type of economic activity. If an enterprise implements production activities, it has its own pharmaceutical products and pharmaceuticals and materials. While trading - the pharmaceutical goods (in retail) and pharmaceutical and medical goods (in wholesale). At the same time, the CTEA does not specify in detail the list of pharmaceutical and medical products, in contrast to pharmaceutical products, preparations and materials that contain the classification of classes for the production of these stocks. Separately in CTEA are distinguished other objects 
and processes of pharmaceutical activity (preparation of herbal raw materials (grinding, sorting, and milling) for the manufacture of pharmaceutical products, research and development in the field of pharmaceuticals and biotechnology in pharmaceuticals, packaging of pharmaceuticals). The objects, which are not included in the pharmaceutical products, drugs and materials, are: herbal infusions; dental fillings and cement; cement for restoration of bone tissues; surgical napkins.

The reflection in the accounting of the above mentioned objects and processes of pharmaceutical activity specified in the CTEA-2010 [9] is summarized in the Table 1.

Place of processes and objects of pharmacy in accounting

Table 1

\begin{tabular}{|c|c|c|c|}
\hline \multirow{2}{*}{ № } & \multicolumn{2}{|c|}{$\begin{array}{l}\text { Types of pharmaceutical activity } \\
\text { according to the CTEA -2010 }\end{array}$} & \multirow{2}{*}{$\begin{array}{l}\text { Results of pharmaceutical activities as objects of } \\
\text { accounting }\end{array}$} \\
\hline & $\begin{array}{l}\text { Economic process of pharmaceutical } \\
\text { company }\end{array}$ & $\begin{array}{c}\text { Raw } \\
\text { material } \\
\text { (substance) }\end{array}$ & \\
\hline 1 & $\begin{array}{c}\text { Production of basic pharmaceutical } \\
\text { products } \\
\text { (Account 23) } \\
\end{array}$ & $\begin{array}{l}\text { Account } \\
201\end{array}$ & $\begin{array}{l}\text { Antibiotics, essential vitamins, salicylic and O- } \\
\text { acetylsalicylic acid, chemically pure sugars, blood, } \\
\text { glands, extracts from glands (Account 26) }\end{array}$ \\
\hline 2 & $\begin{array}{l}\text { Production of pharmaceuticals and } \\
\text { materials } \\
\text { (Account 23) }\end{array}$ & $\begin{array}{l}\text { Account } \\
201,202 \\
022\end{array}$ & $\begin{array}{l}\text { Medicinal products (immune serums, other elements of } \\
\text { blood, vaccines, homeopathic preparations); } \\
\text { contraceptive preparations, medical diagnostic } \\
\text { preparations; medical impregnated cotton wool, gauze, } \\
\text { bandages (Account 26, 022) }\end{array}$ \\
\hline 3 & $\begin{array}{l}\text { Preparation of herbal material } \\
\text { (grinding, sorting, milling) for } \\
\text { production of pharmaceuticals } \\
\text { (Account 23, 941) }\end{array}$ & $\begin{array}{l}\text { Account } \\
201,202 \\
022\end{array}$ & Herbal raw materials (Account 25, 26, 28, 022) \\
\hline 4 & $\begin{array}{l}\text { Research, development and } \\
\text { production of pharmaceuticals in the } \\
\text { field of biotechnology (Account 23) }\end{array}$ & $\begin{array}{l}\text { Account } \\
201\end{array}$ & $\begin{array}{l}\text { Development of new pharmaceuticals or their samples } \\
\text { (Account 26) }\end{array}$ \\
\hline 5 & $\begin{array}{l}\text { Packaging of pharmaceuticals } \\
\text { (Account 23, 93) }\end{array}$ & $\begin{array}{l}\text { Account } \\
28,022 \\
\end{array}$ & $\begin{array}{l}\text { Pharmaceutical preparations } \\
\text { (Account 26, 28, 022) }\end{array}$ \\
\hline 6 & $\begin{array}{l}\text { Production of other objects of } \\
\text { pharmaceutical activity (Account } \\
\text { 23) }\end{array}$ & $\begin{array}{l}\text { Account } \\
201,202, \\
022\end{array}$ & $\begin{array}{l}\text { Herbal tinctures (mint, verbena, chamomile, etc.); } \\
\text { dental fillings and cement; cement for restoration of } \\
\text { bone tissues; surgical napkins (Account 26, 022) }\end{array}$ \\
\hline 7 & $\begin{array}{l}\text { Wholesale trade in pharmaceuticals } \\
\text { and medical goods (Account 36, } \\
\text { 701, 702, 712) }\end{array}$ & $\begin{array}{l}\text { Account } \\
202,25 \\
26,28\end{array}$ & $\begin{array}{l}\text { Pharmaceutical and medical goods } \\
\text { (Account 202, 25, 26, 28) }\end{array}$ \\
\hline 8 & $\begin{array}{l}\text { Retail trade in pharmaceutical } \\
\text { products (Account 301, 311, 701, } \\
\text { 702, 712) }\end{array}$ & $\begin{array}{l}\text { Account } \\
26,28\end{array}$ & Pharmaceutical products (Account 28) \\
\hline
\end{tabular}

Besides CTEA in Ukraine there is another system of classification - Ukrainian Classification of Goods for Foreign Economic Activity (UCGFEA), which is the commodity nomenclature of Customs Tariff of Ukraine (CTU is based on the Harmonized Commodity Description and Coding System of the World Customs Organization and Combined Nomenclature of EU) [10]. The CTU systematizes the goods imported into the territory of Ukraine, and allocates a group of pharmaceutical products (code 30; section VI "Production of chemical and related industries"): 3001 "glands and other organs"; 3002 "blood of humans, animals, immune serums; vaccines, toxins, microorganisms' culture; 3003 “Medicinal products (medicines) consisting of combination of two or more products”; 3004 "medicinal products (medicines) consisting of mixed or non-modified products"; 3005 "cotton wool, gauze, bandages and similar products"; 3006 "Pharmaceutical products (for example, sterile surgical or dental products, reagents, preparations, diagnostic reagents, sanitary bags and sets for first aid, gel preparations, etc.)”. As we see, pharmaceutical products are isolated in a separate group; however, analyzing its components, it is clear that they are mainly medical and dental products.

Except aforementioned pharmaceutical products, other pharmaceuticals, substances and products that 
according to the UCGFEA belong to other commodity positions. In particular it includes: food products, drinks, water distillates, aqueous solutions of essential oils, soaps and other products containing medicinal substances. Consequently, own pharmaceutical products according to UCGFEA represent only a rather small group - it is 3006 . Nevertheless, for accounting purposes and in the modern sense, the list of such goods is much larger, which includes the inclusion of both other groups of pharmaceutical products and pharmaceuticals, different from products belonging to other groups according to UCGFEA.

We also note the existence of the international standard of product classification (SITC Rev. 4) [11], which is guided by the international market of the USA, Germany, Great Britain. The classification of pharmaceutical products is carried out according to the groups of section 54 "Medicines and Pharmaceuticals": 5411 "Provitamins and vitamins (not medicines)"; 5413 "Antibiotics (not medicines)"; 5414 "Plant alkaloids (not prepared as medicines)"; 5415 "Hormones, prostaglandins, thromboxanes and leukotrienes"; 5416 "Glycosides; glands or other organs; antibodies, vaccines"; 5419 "Pharmaceutical products, except for medicines"; 5421 "Medicines containing antibiotics"; 5422 "Medicines containing hormones and others, but not antibiotics"; 5423 "Medicinal products containing alkaloids, but do not contain hormones, etc., or antibiotics"; 5429 "Medicines that not specified anywhere" [12]. As you can see, these groups generally go in line with Ukrainian standards and are not used in Ukraine.

An analysis of classifications of pharmaceutical products at the national level has shown their specific difference. The difference in the application - it is classified and provided a list and brief description of pharmaceutical products and goods in UCGFEA, and in CTEA - 2010 there is classified separately the economic processes of pharmaceutical activities and related results (objects) that affect their reflection in accounting. Taking into account that UCGFEA and CTEA - 2010 are interconnected through a transition of classifiers tables, the objects of pharmaceutical industry generally coincide. The differences occur due to the nature of enterprises and features of classifiers according to their functionality. Let's compare UCGFEA and CTEA - 2010 in the context of pharmaceutical products as objects of Accounting (Table 2).

Summarizing the data of the Table 2, it is possible to systematize all components of pharmaceutical products in accordance with their purpose and use in economic activities and reflection on the accounts in Accounting: 1) goods (account 28) and finished products (account 26) - finished medicines (medicinal products, remedies, drugs); things of medical products; sanitary and hygienic goods; parapharmaceutical goods (products of additional pharmacy assortment); other pharmaceutical products (products); 2) raw materials and materials (account 201) - active pharmaceutical ingredients (medicinal substances, active substances, substances); auxiliary substances; 3) semi-finished products and component parts (account 202) substances (valid or active substances); powders and other ingredients; unpacked mixture, ointments, tinctures, pills; wholesale purchases of medicines and parapharmaceutical products; 4) semi-finished products (own production) (account 25) - herbal raw materials; water distillates; aqueous solutions of essential oils; 5) tolling raw materials (materials accepted for processing (account 022) and materials transferred for processing (account 206)) - medicines and parapharmaceuticals goods, which should be packed and packaged; medicinal raw materials, semi-finished products, which are to be used in the production, processing or passing of another production process under the tiling contract.

\section{Conclusions.}

The conducted research allowed to establish the essence of pharmaceutical products from the standpoint of pharmacy and as an object of Accounting, identify the components of pharmaceutical products and establish their essence. In parallel, it is revealed the correspondence of the groups of pharmaceutical products according to the UCGFEA and CTEA 2010 of Ukraine. It has been established that from the position of Accounting, pharmaceutical products consist of five components (1. goods and finished products; 2) raw and materials and auxiliary materials; 3) purchase semi-finished products and component parts; 4) semi-finished products (own production); 5) tolling raw materials and materials transferred to processing). However, each listed item of goods in the pharmaceutical industry includes substances, products, semifinished products, products and goods that are included in the Accounting for particular type of inventory. The harmonization of the pharmaceutical products in accordance with the domestic activity classifiers and their delimitation as separate objects of accounting will facilitate the further improvement of the accounting of the management of the pharmaceutical enterprise and minimize its production and commercial risks for expansion of economic activity, introduction of the latest technologies and innovative products. 


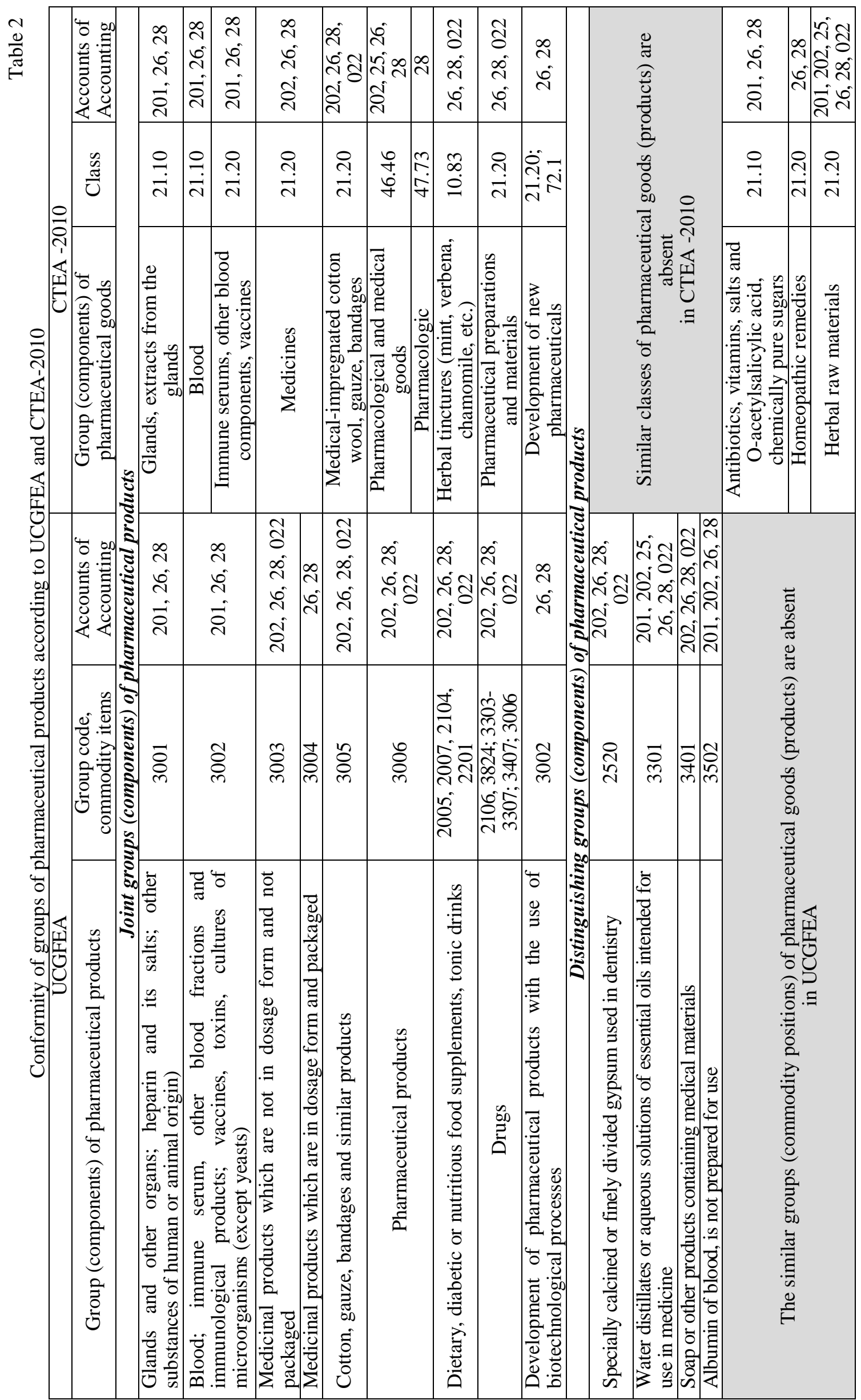




\section{Література}

1. Accounting and Auditing Update [Electronic resource] / Editors J. Khatri, S. Venkateshwaran. — 2015. — № 4. — Available at : https://assets.kpmg.com/content/dam/kpmg/pdf/2016/03/AAU-December2015.pdf

2. International trade in medicinal and pharmaceutical products [Electronic resource] // Eurostat. — 2017. — May. — Available at : http://ec.europa.eu/eurostat/statistics-explained/index.php/International_trade_in_medicinal_and_pharmaceutical_products.

3. Фармацевтичний ринок України: реалії та перспективи. - 2017. — № 6. — Режим доступу: http://ua.lawyers.ua/farmatsevtichnij-rinok-ukrayini-realiyi-ta-perspektivi.html.

4. Financial Aspects and the Future of the Pharmaceutical Industry in the United States of America Mater Sociomed [Electronic resource]. — 2013. — Dec. — № 25 (4). — P. 286 - 29. — Available at : https://www.ncbi.nlm.nih.gov/pmc/articles/PMC3914743.

5. Положення (стандарт) бухгалтерського обліку 9 «Запаси» [Електронний ресурс] / Міністерство фінансів України. - 1999. — Режим доступу : http://zakon4.rada.gov.ua/laws/show/ z0751-99 (дата звернення: 28.04.2017).

6. Чижевська Л. В. Словник економічних термінів: економічна теорія, бухгалтерський облік / Л. В. Чижевська, Д. Л. Лозинський ; за ред. проф. Ф. Ф. Бугинця. - Житомир : ЖДТУ, 2011. — 160 с.

7. Фармацевтична енциклопедія [Електронний ресурс]. — Режим доступу : http://www.pharmencyclopedia.com.ua (дата звернення: 28.04.2017).

8. Про лікарські засоби: Закон України (введений в дію Постановою ВР

№ 124/96-ВР від 04.04.96 $\square$ Електронний ресурс $\square$ / Верховна Рада України. — Режим доступу : http://zakon2.rada.gov.ua/laws/show/123/96-\%D0\%B2\%D1\%80 (дата звернення: 28.04.2017)

9. Класифікація видів економічної діяльності (КВЕД-2010) [Електронний ресурс] / Evrovektor. — Режим доступу : http://evrovektor.com/kved/2010/ (дата звернення: 01.04.2017).

10. Митний тариф України (Додаток до Закону України "Про Митний тариф України" від 19 вересня 2013 року № 584-VII) [Електронний ресурс] // Законодавство України. — Режим доступу : http://zakon3.rada.gov.ua/laws/show/584\%D0\%B0-18 (дата звернення: 01.04.2017).

11. Standard International Trade Classification [Electronic resource] / United Nations. Department of Economic and Social Affairs. Statistics Division. Statistical Papers Series M. - №. 34. - C. 44-46. - Available at: https://unstats.un.org/unsd/pubs/gesgrid.asp?mysearch=Standard+International+Trade+Classification+\%28SITC\%29+Revision+4.

12. Accounting and Financial Reporting Update — Including Interpretive Guidance [Electronic resource]. — 2016. — 91 p. — Available at : https:/www2.deloitte.com/content/dam/Deloitte/us/Documents/audit/us-aers-life-science-accounting-and-financial-reportingupdate-including-interpretive-guidance-march-2016.pdf

$$
\begin{aligned}
& \text { Стаття рекомендована до друку 10.12.2018 } \\
& \text { Гр Скрипник М.I., Вигівська I.М., } \\
& \text { Грабчук I.Л., Григоревська O.O. }
\end{aligned}
$$

1. Khatri, J., \& Venkateshwaran, S. (Eds.) (2015). Accounting and Auditing Update, 4. Retrieved from https://assets.kpmg.com/content/dam/kpmg/pdf/2016/03/AAU-December.pdf.

2. International trade in medicinal and pharmaceutical products (2017, May). Eurostat. Retrieved from http://ec.europa.eu/eurostat/statistics-explained/index.php/International_trade_in_medicinal_and_pharmaceutical_products.

3. Farmatsevtychnyi rynok Ukrainy: realii ta perspektyvy [Pharmaceutical market of Ukraine: realities and prospects]. (2017). (Vol. 6). Retrieved from http://ua.lawyers.ua/farmatsevtichnij-rinok-ukrayini-realiyi-ta-perspektivi.html [in Ukrainian].

4. Financial Aspects and the Future of the Pharmaceutical Industry in the United States of America Mater Sociomed. (2013, Dec.) (Vol. 25 (4)), (P. 286 - 29). Retrieved from https://www.ncbi.nlm.nih.gov/pmc/articles/PMC3914743/.

5. Ministerstvo finansiv Ukrainy [Ministry of Finance of Ukraine]. (1999). Polozhennia (standart) bukhhalterskoho obliku 9 «Zapasy» [Regulation (standard) of accounting 9 "Stocks"]. Retrieved from http://zakon4.rada.gov.ua/laws/show/ z0751-99 [in Ukrainian].

6. Chyzhevska, L. V., \& Lozynskyi, D. L. (2011). Slovnyk ekonomichnykh terminiv: ekonomichna teoriia, bukhhalterskyi oblik [Dictionary of economic terms: economic theory, accounting]. Zhytomyr: ZhDTU [in Ukrainian].

7. Farmatsevtychna entsyklopediia [Pharmaceutical Encyclopedia]. (n. d.). www.pharmencyclopedia.com.ua. Retrieved from http://www.pharmencyclopedia.com.ua [in Ukrainian].

8. Verhovna Rada Ukrainy. (1996.) Pro likarski zasoby: Zakon Ukrainy [On Medicines: The Law of Ukraine]. Retrieved from http://zakon2.rada.gov.ua/laws/show/123/96-\%D0\%B2\%D1\%80 [in Ukrainian].

9. Evrovektor. (2010). Klasyfikatsiia vydiv ekonomichnoi diialnosti (KVED-2010) [Classification of Types of Economic Activities (CED-2010)]. Retrieved from http://evrovektor.com/kved/2010/ [in Ukrainian].

10. Mytnyi taryf Ukrainy [Customs tariff of Ukraine]. (2013, September 19). Zakonodavstvo Ukrainy — Legislation of Ukraine. Retrieved from http://zakon3.rada.gov.ua/laws/show/584\%D0\%B0-18 [in Ukrainian].

11. United Nations. Department of Economic and Social Affairs. Statistics Division. (n. d.). Standard International Trade $\begin{array}{lllllllll}\text { Classification } & \text { Revision } & 4 & \text { Statistical } & \text { Papers } & \text { Series } & M & 34 . & \text { Retrieved from }\end{array}$ https://unstats.un.org/unsd/pubs/gesgrid.asp?mysearch=Standard+International+Trade+Classification+\%28SITC\%29+Revision+4.

12. Accounting and Financial Reporting Update - Including Interpretive Guidance. (2016). Retrieved from https:/www2.deloitte.com/content/dam/Deloitte/us/Documents/audit/us-aers-life-science-accounting-and-financial-reporting-update-includinginterpretive-guidance-march-2016.pdf.

The article is recommended for printing 10.12.2018

(C) Skrypnyk M.I., Vyhivska I.M., Grabchuk I.L., Hryhorevska O.O. 